\title{
Transfer of Radiocesium into Wild Boar Meat
}

\author{
Petr Dvořák ${ }^{1}$, Petr Snášel ${ }^{1}$, Katarína Beňová \\ 1) Department of Biochemistry, Chemistry and Biophysics, Faculty of Veterinary Hygiene and Ecology, \\ University of Veterinary and Pharmaceutical Sciences Brno, Czech Republic \\ 2) Department of Biology and Genetics, University of Veterinary Medicine Košice, \\ Slovak Republic
}

Received March 6, 2009

Accepted June 30, 2009

\begin{abstract}
The aim of the study was to find the sources of ${ }^{137} \mathrm{Cs}$ in wild boar food in the natural ecosystem. The main emphasis is focused on the analyses of wild boar muscles and the content of wild boar stomach. Boars weighing 20 to $100 \mathrm{~kg}$ were killed at two locations. The highest specific activities of muscles were measured in boars originated from the Dvorce location; the average specific activity in boars killed on 14 April 2007 and 9 March 2008 achieved $132 \mathrm{~Bq} \cdot \mathrm{kg}^{-1}$. Due to high fluctuation the differences between the mean values of $31 \mathrm{~Bq} \cdot \mathrm{kg}^{-1}$ in males and $43 \mathrm{~Bq}^{\mathrm{kg}} \mathrm{kg}^{-1}$ in females were not significant. Earthworms from grass fields with a specific activity of $16 \mathrm{~Bq} \cdot \mathrm{kg}^{-1}$, rootlets from the Šabrava location with $200 \mathrm{~Bq} \cdot \mathrm{kg}^{-1}$ and Elaphomyces granulatus fruiting bodies with $4,743 \mathrm{~Bq} \cdot \mathrm{kg}^{-1}$ and $2,858 \mathrm{~Bq} \cdot \mathrm{kg}^{-1}$ are the components of boar food with the ${ }^{137} \mathrm{Cs}$ specific activities higher than that of the detection limit. Consequently, underground mushrooms probably represent the main source of radiocesium in the food chain of boars. A remarkable reduction of ${ }^{137} \mathrm{Cs}$ specific activities in boar muscles is not expected at the post-Chernobyl radiocesium contaminated locations with the occurrence of Elaphomyces granulatus within next two decades.
\end{abstract}

Sus scrofa, ${ }^{137} \mathrm{Cs}$, Elaphomyces granulatus, radioecology, Chernobyl, radionuclide migration, ingestion, foot

The consequences of nuclear accidents can have a long-term effect on some biocenoses. It is caused by the transfer capability of some radionuclides that move from the abiotic environmental components to the biotic component and accumulate in it. One of them is the ${ }^{137} \mathrm{Cs}$ radionuclide, i.e. the primary post-Chernobyl nuclide (with its physical half-life of about 30 years), that was shortly accompanied by ${ }^{134} \mathrm{Cs}$ (with its physical half-life of about 2 years) after the disaster, both with the chemical behaviour similar to that of potassium (Garger et al. 2006; Rajec et al. 2009).

After successive reduction of the radiocesium activity in muscles of fair game, an unexpected reversal occurred in the 1990s. After floods in the North-Eastern Moravia in June 1997, the radiocesium activity increased in the muscles of fair game (in 183 specimens examined by the State Veterinary Administration). This mainly pertained to boars and ungulate game with the exception of mountain goats. According to the State Veterinary Administration of the Czech Republic, the average activities were $61 \mathrm{~Bq} \cdot \mathrm{kg}^{-1}$ from 1992 to June 1997, $588 \mathrm{~Bq} \cdot \mathrm{kg}^{-1}$ from July 1997 to 2000 , followed by reduction to the average of $101 \mathrm{~Bq} \cdot \mathrm{kg}^{-1}$ observed during the years 2001 and 2002. Specific activities that exceeded $1,250 \mathrm{~Bq} \cdot \mathrm{kg}^{-1}$ were randomly detected in boars after the flood in North-Eastern Moravia, i.e. values that exceeded the maximum permissible activity (Decree of SÚJB 2002). Such values were detected in four specimens (from 1,649 to $7,510 \mathrm{~Bq} \cdot \mathrm{kg}^{-1}$ ).

Resorption of radiocesium $\left({ }^{137} \mathrm{Cs}\right)$ in the digestive tract of vertebrates is relatively high (50\% and more). Resorption can reach up to $80 \%$ in ruminants whereas $100 \%$ can be reached in monogastric animals (especially carnivores). The wild boar belongs to animals whose origins of ${ }^{137} \mathrm{Cs}$ have not been exactly explained yet.

Address for correspondence:

Prof. MVDr. Petr Dvořák, CSc.

Department of Biochemistry, Chemistry and Biophysics,

Faculty of Veterinary Hygiene and Ecology

University of Veterinary and Pharmaceutical Sciences Brno

Palackého 1-3, 61242 Brno, Czech Republic 
The importance of radiocesium exposure of human beings by ingestion of boar meat seems to be negligible due to low consumption of wild boar meat in the Czech and Slovak Republics (about $0.5 \mathrm{~kg}$ a year). However, the radiological risk of a critical group should not be underestimated. For example, the consumption of wild boar meat by members of hunting associations is higher by nearly two orders than that of the rest of the population, exceeding sometimes more than a half of other yearly meat consumption. Ecological halflife models (Lettner et al. 2009) can be used as valuable and effective tools to specify the countermeasures for contamination reduction or meat consumption regulation. Cooking or salting, including meat brining can take part in such countermeasures (Dvořák at al. 2008).

The explanation of radiocesium transfer into the digestive tract and consequently the transfer of radiocesium into the wild boar muscles is of great importance as the knowledge of this process might contribute to the development of countermeasures against possible muscle contamination.

Therefore, the aim of this study was to explain the source of ${ }^{137} \mathrm{Cs}$ in wild boar food in the natural ecosystem with the main emphasis on analyses of muscles and the content of stomach, and to find possible dependence of ${ }^{137} \mathrm{Cs}$ activity in muscles on the sex of animals.

\section{Materials and Methods}

Wild boars weighing 20 to $100 \mathrm{~kg}$ originated from two adjacent locations (Šabrava and Dvorce) situated in the Odry Highlands and partly in the Nízký Jeseník mountains. The landscape is a typical upland (600 m above sea level on the average) with rich spruce forests, at lower altitudes with mixed forests and isolated beech and birch forests, and willows and alders near watercourses. There are large meadowlands and grasslands situated among individual forests. Arable land is quite rare; small-scale watercourses that formed deep valleys by erosion activity have strongly affected the landscape.

Twenty two muscle samples and eleven samples of the stomach content were taken from wild boars of the weight ranging from 20 to $100 \mathrm{~kg}$ from 8 November 2006 to 4 April 2008 to determine the ${ }^{137} \mathrm{Cs}$ specific activities. Twenty surface land samples were collected from the places rooted by animals and up to a distance of $2 \mathrm{~m}$ from them. All typical food items were collected, i.e. soil, needles, earthworms, beechnuts, rootlets, and mushroom Elaphomyces granulatus). Some additional foods (maize silage, sugar slices and oat) were also included.

Stomach content sample with the specific activity of $100 \mathrm{~Bq} \cdot \mathrm{kg}^{-1}$ was rinsed by water and sorted according to the grain size on the $1 \mathrm{~mm}$ screen. The samples were not dried; all were measured in their native state or cooled to a temperature of $-15^{\circ} \mathrm{C}$, and then measured.

The ${ }^{137} \mathrm{Cs}$ specific activities were measured using gamma-spectrometry with the semiconductor HPGe GC2020 detector (efficiency of $20 \%$, resolution at $1.3 \mathrm{MeV}$ of $1.8 \mathrm{keV}$ ) and the Inspector multichannel analyser.

Three measurement geometries (i.e. methods of measurements) were used in this study: muscles were measured in the Marinelli beaker $(450 \mathrm{ml})$, the contents of stomach and other potential radiocesium sources in $200 \mathrm{ml} \mathrm{PE}$ bottles $(200 \mathrm{ml})$ and separated parts of stomach in Petri dishes $(10 \mathrm{ml})$. All geometries including the gammaspectrometric system were certified in the Czech Metrological Institute. The following minimum detectable activities (MDA) for the measuring time of $3 \mathrm{~h}$ were determined: $0.9 \mathrm{~Bq} \cdot \mathrm{kg}^{-1}$ in the Marinelli beaker, $5.2 \mathrm{~Bq} \cdot \mathrm{kg}^{-1}$ in PE bottles and $83 \mathrm{~Bq} \cdot \mathrm{kg}^{-1}$ in Petri dishes. However, the measuring time was extended for some samples to 18 $\mathrm{h}$ with the following MDA: $0.4 \mathrm{~Bq} \cdot \mathrm{kg}^{-1}$ in the Marinelli beaker, $2.2 \mathrm{~Bq} \cdot \mathrm{kg}^{-1}$ in PE bottles and $10 \mathrm{~Bq} \cdot \mathrm{kg}^{-1}$ in Petri dishes. The combined relative standard uncertainties were calculated according to the Guide (1993). Details of the system were described by Dvořák et al. (2006).

Statistics were evaluated by means of the basic parameters (modus, mean, and median) and by the polynomial curves describing the time trends. The effect of sex on the muscle activity concentrations was assessed by means of paired $t$-test with non-homogeneous variation.

\section{Results}

Higher specific activity of $534 \mathrm{~Bq} \cdot \mathrm{kg}^{-1}$ in the soil at the Dvorce location was measured in comparison to the specific activities of $173 \mathrm{~Bq} \cdot \mathrm{kg}^{-1}$ in the soil at the Šabrava location. The specific activity of earthworms was $16 \mathrm{~Bq} \cdot \mathrm{kg}^{-1}$, and the specific activity of rootlets collected at the Šabrava location was higher than that of the pure soil of this locality $\left(2,000 \mathrm{~Bq} \cdot \mathrm{kg}^{-1)}\right.$. Spruce roots and grass at the Šabrava location achieved the specific activities of 62 and $65 \mathrm{~Bq} \cdot \mathrm{kg}^{-1}$ while sedges reached only $24 \mathrm{~Bq} \cdot \mathrm{kg}^{-1}$. The highest specific 
activities were measured in Elaphomyces granulatus - underground mushroom at the Sabrava location with the values of $4,743 \mathrm{~Bq} \cdot \mathrm{kg}^{-1}$ and $2,858 \mathrm{~Bq} \cdot \mathrm{kg}^{-1}$. However, most components of food found in the stomach content manifested specific activities lower than the minimum detectable activity.

The highest activity of muscles was measured in boars killed at the Dvorce location; the average specific activity of $132 \mathrm{~Bq} \cdot \mathrm{kg}^{-1}$ was measured in the samples taken on 14/4/2007 and $9 / 3 / 2008$. The following results were detected in the samples taken in July 2007 in Dvorce: $89 \mathrm{~Bq} \cdot \mathrm{kg}^{-1}$ and $78 \mathrm{~Bq} \cdot \mathrm{kg}^{-1}$; and in January 2008 in Dvorce: $64 \mathrm{~Bq} \cdot \mathrm{kg}^{-1}$ and $68 \mathrm{~Bq} \cdot \mathrm{kg}^{-1}$. On the other hand, the specific activities of $20 \mathrm{~Bq} \cdot \mathrm{kg}^{-1}$ at the Šabrava location and $27 \mathrm{~Bq} \cdot \mathrm{kg}^{-1}$ at the Dvorce location were measured in samples taken in the second half of November. In other samples, except for the samples collected in November, January and April, the specific activities were very low, in fact lower than the minimum detectable activity ( 5 samples).

Fig. 1 shows the time trend of the ${ }^{137} \mathrm{Cs}$ seasonal activity variations in muscles and in the contents of stomach. The maximum specific activity in muscle was measured twice in April with the maximum specific activity in the stomach content always preceding.

The difference of the means of $31 \mathrm{~Bq} \cdot \mathrm{kg}^{-1}$ for males and $43 \mathrm{~Bq} \cdot \mathrm{kg}^{-1}$ for females was not significant due to considerable fluctuations. The effect of sex on the activity in muscles was not proved.

Fig. 2 shows the specific activity in the stomach content and the corresponding specific activities in muscles of 11 boars. The maximum specific activity of $100 \mathrm{~Bq} \cdot \mathrm{kg}^{-1}$ in the stomach content was detected in a boar at the Dvorce location while the corresponding specific activity of $68 \mathrm{~Bq} \cdot \mathrm{kg}^{-1}$ was detected in muscle of the same boar. The highest specific activity was $89 \mathrm{~Bq} \cdot \mathrm{kg}^{-1}$ in boar muscle and the corresponding specific activity of the stomach content was below MDA. The individual relationships and the considerable fluctuations between the specific activity in the stomach content and muscles of the particular animals are shown in Fig. 2.

\section{Discussion}

Live microbial biomass is the primary indicator of the ${ }^{137} \mathrm{Cs}$ transfer from soil into the ecosystems. Only minimum ${ }^{137} \mathrm{Cs}$ quantity is deposited in the live microbial biomass, but

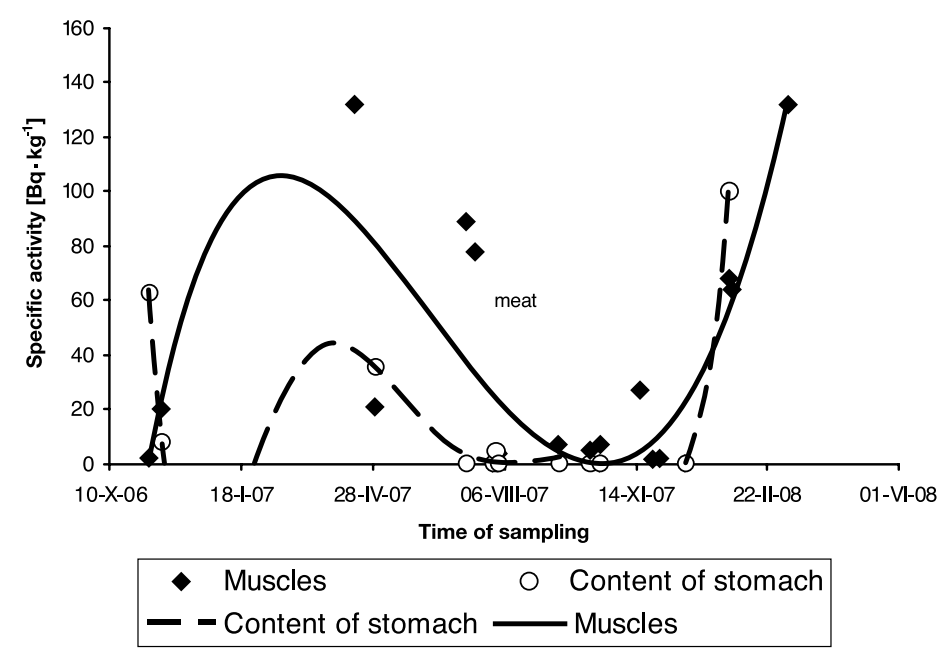

Fig. 1. The time trend of the ${ }^{137} \mathrm{Cs}$ specific activities in muscles and in the content of stomach 


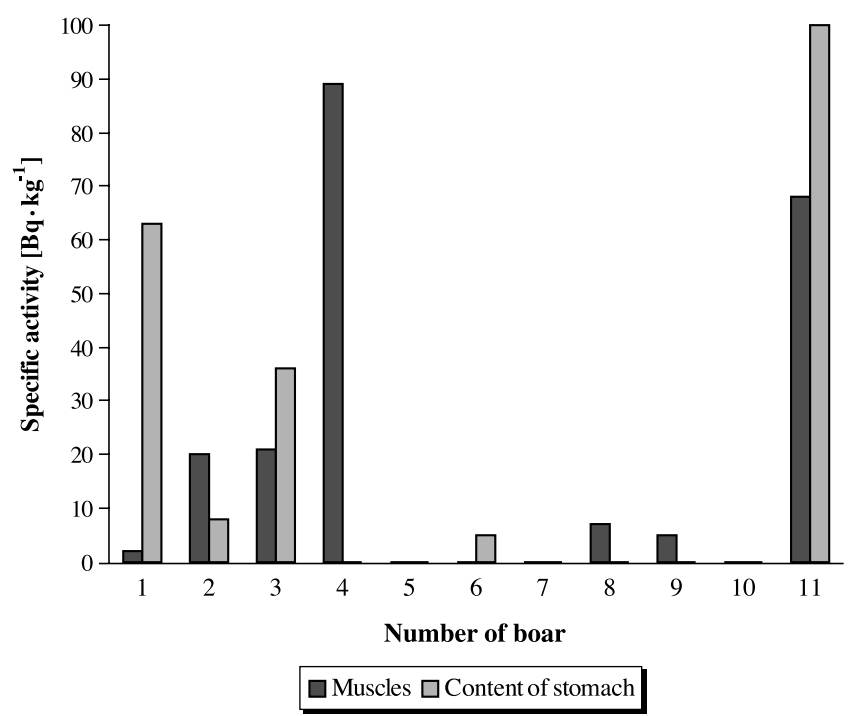

Fig. 2. The comparison of ${ }^{137} \mathrm{Cs}$ specific activities in the stomach contents and in muscles of wild boars

a positive correlation was found between the transfer factor of soil/plant and mushroom biomass (Stemmer et al. 2005). This has proved the importance of all mushrooms in the radiocesium distribution while the ${ }^{137} \mathrm{Cs}$ resorption is higher by one order for mushrooms compared to other plants (Sato shi et al. 1998). The accumulation capability of radiocesium in mushrooms is not clear. The ${ }^{137} \mathrm{Cs}$ specific activities depend on the species of mushroom, soil contamination, substrate, humidity and time, and/or other ion concentrations. Xercomus badius, X. chrysenteron, Suillus variegatus, Cantharellus tubaeformis, C. lutescens, Rozites caperata, Hydnum repandum, Laccaria amethystina, Russula cyanoxantha belong to species of mushrooms with above-ground fruiting bodies that have the maximum capability to accumulate radiocesium (Rückert and Diehl 1987; Satoshi et al. 1998; Kalač 2001; Felitz 2005; Dvořák et al. 2006).

Detailed investigation of the environment and food chain of forest ecosystems found a high activity of the underground fruiting bodies of the mushroom genus of Elaphomyces $\mathrm{sp}$. that were primarily located in spruce forests. The absolutely highest ${ }^{137} \mathrm{Cs}$ specific activity of $25,660 \mathrm{~Bq} \cdot \mathrm{kg}^{-1}$ was detected in the fruiting bodies found in a Bavarian forest (Felitz 2005) whereas the specific activities reached their maximum between 800 to $18,800 \mathrm{~Bq} \cdot \mathrm{kg}^{-1}$ in less contaminated regions, e.g., in Rhineland, Germany (Hohmann and Huckschlag 2005). The above mentioned specific activities exceeded at least by one order the specific activities measured in all other above-ground fruiting bodies and other plant and animal samples (Hohmann and Huckschlag 2005). Seasonal variations of the ${ }^{137} \mathrm{Cs}$ specific activities in muscle samples of boars in forests in the south Rhineland $(50 \%$ pine forests and $20 \%$ spruce forests representing $90 \%$ of the land area) were revealed between January 2001 and February 2003. The fluctuation was characteristic with higher incidence of specific activities higher than $600 \mathrm{~Bq} \cdot \mathrm{kg}^{-1}$ in muscle during two summer seasons (from March to September), i.e. $26 \%$ and $24 \%$, and with their lower incidence in three winter seasons $(9.3 \%, 7.9 \%$ and $1 \%)$. The stomach contents were examined as well. A positive correlation $(0.66)$ for the activity of the stomach contents and the activity of muscle was found, but the stomach contents were usually less contaminated compared to muscles; the median of the stomach content was $22 \mathrm{~Bq} \cdot \mathrm{kg}^{-1}$, the maximum $1,749 \mathrm{~Bq} \cdot \mathrm{kg}^{-1}$, while the 
median of muscle was $129 \mathrm{~Bq} \cdot \mathrm{kg}^{-1}$, and the maximum 5,573 $\mathrm{Bq} \cdot \mathrm{kg}^{-1}$. No difference in the specific activities of female and male muscles was proved (Hohmann and Huckschlag 2005).

In Croatia, some locations were monitored during the years 2000 and 2002 (Vilic et al. 2005); radiocesium in boar muscles ranged from 0.4 to $611.5 \mathrm{~Bq} \cdot \mathrm{kg}^{-1}$. The highest muscle contamination was observed in autumn. The authors interpreted this fact as a result of higher mushroom intake by boars at that time.

Radiocesium transfer into boar muscles was monitored at two locations in Northern Austria (Strebl and Tataruch 2007) from 1986 to 2003. Interestingly, the ecological halflife in boars was highly variable compared to deer, with an increasing tendency in recent years. The seasonal variations were similar to those of the neighbouring Germany, i.e. the highest contamination was detected in the first half of year.

The ecological ${ }^{137} \mathrm{Cs}$ half-life is usually markedly longer than the effective half-life, and extremely important in terms of prognosis determination. The relations between the ecological and effective half-lives were studied by Lettner et al. (2009).

The results of stomach content analysis showed the considerable importance of additional feeding and beechnuts in the food of boars while rootlets and sprouts were less important, and the importance of animal components was minimal. Mushrooms were not identified in any stomach, probably due to their relatively high digestibility in boars. Furthermore, the following food components of boars manifested the ${ }^{137} \mathrm{Cs}$ specific activities higher then MDA in the samples tested: $16 \mathrm{~Bq} \cdot \mathrm{kg}^{-1}$ in meadow earthworms, $200 \mathrm{~Bq} \cdot \mathrm{kg}^{-1}$ in rootlets at the Šabrava location, and finally $4,743 \mathrm{~Bq} \cdot \mathrm{kg}^{-1}$ and $2,858 \mathrm{~Bq} \cdot \mathrm{kg}^{-1}$ in Elaphomyces granulatus fruiting bodies. The fruiting bodies were not found in the boar stomach as other mushrooms, however, they were found in the marginal areas around the rooted locations. We may assume that this mushroom with a vegetation season from September to April is searched and consumed by boars, similarly as e.g. the truffles in France. For example, considering the high activity of $4,743 \mathrm{~Bq} \cdot \mathrm{kg}^{-1}$ measured in one sample and taking into account the high mushroom digestibility in boars, the specific activity of chyme can be estimated to about $237 \mathrm{~Bq} \cdot \mathrm{kg}^{-1}$ only due to the intake of the mushroom when $5 \%$ intake in 1 $\mathrm{kg}$ of the stomach content was taken into account. For monogastric animals, the radiocesium resorption can reach up to $100 \%$ while excretion is about $25 \%$, which would mean a daily growth of specific activities of $21 \mathrm{~Bq} \cdot \mathrm{kg}^{-1}$ in the net muscle weight of $25 \mathrm{~kg}$ (for a boar life weight of $100 \mathrm{~kg}$ and food consumption of $3 \mathrm{~kg}$ daily). However, such chyme usually does not consist only of the fruiting bodies of the above mentioned mushroom and other components with the specific activities below MDA. The following example based on our results (muscle sample with the specific activities of $4,743 \mathrm{~Bq} \cdot \mathrm{kg}^{-1}$, soil elements 173 $\mathrm{Bq} \cdot \mathrm{kg}^{-1}$, rootlets $200 \mathrm{~Bq} \cdot \mathrm{kg}^{-1}$, earthworms $16 \mathrm{~Bq} \cdot \mathrm{kg}^{-1}$, all at the Sabrava location) shows the importance of other ${ }^{137} \mathrm{Cs}$ sources. The proved presence of soil, earthworms, rootlets and other components increases the ${ }^{137} \mathrm{Cs}$ activity in the stomach content. In case of food consumption of $3 \mathrm{~kg} \cdot \mathrm{day}^{-1}$ at the Šabrava location with the individual contributions, i.e. $5 \%$ fruiting body of Elaphomyces granulatus (total $711 \mathrm{~Bq}$ ), 5\% soil elements (26 Bq), 20\% rootlets $(120 \mathrm{~Bq}), 2 \%$ earthworms $(1 \mathrm{~Bq})$ and other components with the specific activities below MDA, the total activity of the stomach content would be $858 \mathrm{~Bq}$ per day. For the stomach content of $1 \mathrm{~kg}$, this means the specific activity of $286 \mathrm{~Bq} \cdot \mathrm{kg}^{-1}$. The daily increase of the specific activity in muscle would be $26 \mathrm{~Bq} \cdot \mathrm{kg}^{-1}$. However, the increase due to other components in the food chain is only $5 \mathrm{~Bq} \cdot \mathrm{kg}^{-1}$, i.e. an increase by $25 \%$.

Hohmann and Huckschlag (2005) stated that a higher contribution of additional feeding was recorded in the least contaminated stomach contents of boars in southern regions of Germany. A higher fraction of Elaphomyces granulatus was recorded in the most contaminated stomach contents. The surface activity in these locations ranged from 2.7 to $10.5 \mathrm{kBq} \cdot \mathrm{m}^{-2}$ while the specific activity of the mushroom was reported from 800 to $18,800 \mathrm{~Bq} \cdot \mathrm{kg}^{-1}$. 
According to Felitz (2005), the average specific activity of plants was lower than $1,000 \mathrm{~Bq} \cdot \mathrm{kg}^{-1}$ in ferns (Dryopteris carthusiana) and bilberries (Vaccinium myrtillus). Contamination of above-ground fruiting bodies ranged from $24 \mathrm{~Bq} \cdot \mathrm{kg}^{-1}$ (Macrolepiota procera) to $2,800 \mathrm{~Bq} \cdot \mathrm{kg}^{-1}$ (Xerocomus badius). However, the average specific activities of $26,800 \mathrm{~Bq} \cdot \mathrm{kg}^{-1}$ in the above-ground fruiting bodies of Elaphomyces granulatus many times exceeded the specific activities of other food components of the wildlife game. It was very important especially for boars. Our study shows that Elaphomyces granulatus mushroom must be considered as the most important source of ${ }^{137} \mathrm{Cs}$ because it considerably contributes to the ${ }^{137} \mathrm{Cs}$ intake $(82 \%)$.

In the following two decades, we do not expect any long-term reduction of ${ }^{137} \mathrm{Cs}$ specific activity in wild boar muscles in the post-Chernobyl ${ }^{137} \mathrm{Cs}$ contaminated locations with the presence of Elaphomyces granulatus. The only exception can be in the years with a large beechnut yield when wild boars prefer beechnuts in their food and the specific activity in wild boar muscle can decrease. Additional feeding with non-contaminated feed seems to be very important as it may reduce the wild boar intake of mushrooms. This would markedly reduce the muscle contamination, and consequently the risk of internal contamination of the human population by the wild boar meat consumption as well.

\section{Transfer radiocesia do masa prasete divokého}

Cílem práce je objasnit zdroj ${ }^{137} \mathrm{Cs}$ v potravě prasete divokého v přírodním ekosystému s hlavním důrazem na analýzy svaloviny a obsahu žaludků. Divoká prasata s hmotností od 20 do $100 \mathrm{~kg}$ pocházela ze dvou lokalit. Nejvyšší měrné aktivity svaloviny byly naměřeny u prasat ulovených v lokalitě Dvorce ze vzorků odebraných 14.4.2007 a 9.3.2008 o průměrné hodnotě $132 \mathrm{~Bq} \cdot \mathrm{kg}^{-1}$. Střední hodnoty dosáhly $31 \mathrm{~Bq} \cdot \mathrm{kg}^{-1} \mathrm{u}$ samců a $43 \mathrm{~Bq} \cdot \mathrm{kg}^{-1}$ u samic. Rozdíl nebyl vzhledem k značnému rozptylu statisticky významný. Ke komponentám potravy prasete divokého $\mathrm{s}$ aktivitami ${ }^{137} \mathrm{Cs}$, které nebyly pod mezí detekce, patří žížaly z louky $16 \mathrm{~Bq} \cdot \mathrm{kg}^{-1}$, kořínky z lokality Šabrava $200 \mathrm{~Bq} \cdot \mathrm{kg}^{-1}$ a plodnice Elaphomyces granulatus 4743 a $2858 \mathrm{~Bq} \cdot \mathrm{kg}^{-1}$. Právě tato podzemní houba představuje hlavní zdroj radiocesia v potravním řetězci divokých prasat. $V$ dalších dvou desetiletích se tak na postčernobylským radiocesiem kontaminovaných lokalitách s výskytem Elaphomyces granulatus nedá očekávat výrazný pokles aktivity ${ }^{137} \mathrm{Cs}$ ve svalovině prasete divokého.

\section{Acknowledgment}

This study was funded by the grant no. MSM6215712402 of the Ministry of Education, Youth and Sports of the Czech Republic.

\section{References}

Decree of SÚJB on Radiation Protection No. 307/2002 Coll., 6362-6541 as amended in Decree of SÚJB No. 499/2005 Coll. 9806-9830

Dvořák P, Kunová V, Beňová K, Ohera M 2006: Radiocesium in mushrooms from selected locations in the Czech Republic and the Slovak Republic. Radiat Environ Biophys 45: 145-151

Dvořák P, Kunová V, Kunová J, Beňová K 2008: Radiocesium activity reduction in boar meat by brinning. Radiat Environ Biophys 47: 179-182

Guide to the Expression of Uncertainty in Measurement for Standardization, first edition 1993, corrected and reprinted 1995, International Organization for Standardization (Geneva, Switzerland)

Garger EK, Kashpur VA, Li WB, Tschierch J 2006: Radioactive aerosols released from the Chernobyl Shelter into the immediate environment. Radiat Environ Biophys 45: 105-114

Felitz U 2005. Investigations on the behaviour of ${ }^{137} \mathrm{Cs}$ in wild boar and other bioproducts of forests. Environmental Studies: Final Report Summary of the research project StSch 4324, Federal Ministery for Environment. Nature Protection, and Reactor Safety, (http://www.environmental-studies.de/Radioecology/Radiocesium)

Hohmann U, Huckschlag D 2005: Investigations on the radicaesium of wild boar (Sus scrofa) meat in Rhineland - Palatine: a stomach content analysis. Eur J Wildlife Res 51: 263-270

Kalač P 2001: A review of edible mushroom radioactivity. Food Chemistry, 75, s. 29-35

Lettner H, Hubmer A, Bossew P, Strebl F, Steinhäusler F 2009: Effective and ecological half-lives of Cs-137 in cow's milk in alpine agriculture. Radiat Environ Biophys 48: 47-56 
Rajec P, Mátel L, Rosskopfová O, Dulanská S, Galanda D 2009: Determination of radionuclides in environmentals samples. In: New Techniques for the detection of nuclear and radioactive Agents. Nato Science for and security Series-B: Physics and Biophysics. Springer pp. 273-285

Rückert G, Diehl JF 1987: Increased levels of cesium-137 and cesium-134 in 34 mushroom species following the reactor accident at Chernobyl. Z Lebens Unters FA 185: 91-7

Satoshi Y, Yoshida A, Muramatsu Y 1998: Concentrations of Alkali and Alkaline Earth Elements in Mushrooms and Plants Collected in a Japanese Pine Forest, and their Relationship with ${ }^{137}$ Cs. J Environ Radioactiv 41: 183-205

Stemmer M, Hromatka A, Lettner H, Strebl F 2005: Radiocesium storage in soil microbial biomass of undisturbed alpine meadow soils and its relation to ${ }^{137} \mathrm{Cs}$ soil-plant transfer. J Environ Radioactiv 79: 107-118

Strebl F, Tataruch F 2007: Time trends (1986-2003) of radiocesium transfer to roe deer and wild boar in two Austrian forest regions J Environ Radioactiv 98: 137-152

Vilic M, Barisic D, Kraljevic P, Lulic S 2005: ${ }^{137}$ Cs concentration in meat of wild boars (Sus scrofa) in Croatia a decade and half after the Chernobyl accident. J Environ Radioactiv 81: 55-62 
